\title{
Assessment of Air Bengkulu (Indonesia) watershed based on agroecosystem landscape quality and sustainable land use plan
}

\author{
MUHAMMAD FAIZ BARCHIA ${ }^{1, \bullet}$, BAMBANG SULISTYO ${ }^{1}$, KANANG S. HINDARTO ${ }^{1}$, HERY SUHARTOYO ${ }^{2}$ \\ ${ }^{1}$ Department of Soil Science, Faculty of Agriculture, Universitas Bengkulu. Jl. WR. Supratman, Bengkulu City 38371, Bengkulu, Indonesia. \\ Tel.: +62-736-21170, Fax.: +62-736-22105, •email: faizbarchia@unib.ac.id \\ ${ }^{2}$ Department of Forestry, Faculty of Agriculture, Universitas Bengkulu. Jl. WR. Supratman. Bengkulu City 38371, Bengkulu, Indonesia
}

Manuscript received: 20 September 2020. Revision accepted: 26 October 2020.

\begin{abstract}
Barchia MF, Sulistyo B, Hindarto KS, Suhartoyo H. 2020. Assessment of Air Bengkulu (Indonesia) watershed based on agroecosystem landscape quality and sustainable land use plan. Biodiversitas 21: 5422-5430. This study purposes to assess agroecosystem landscape based on land quality values and current land use and assess agro-ecosystem matrices with agricultural conservation practices in Air Bengkulu Watershed conducted from August to December 2019. Spatial analysis used some map and Landsat 8 OLI satellite imagery and ArcGIS version 10.1. The analysis depicted spatial distribution of soil and land quality, land uses, agricultural landscape matrices, and sustainable agro-ecosystems. The assessments revealed soil quality covered Air Bengkulu Watershed categorized moderate $33.1 \%$ to good $14.4 \%$ suitable for sustainable agroecosystems while in marginal quality $38.9 \%$ mostly lying on the upstream. This unique landscape formed a land quality prone to degradation because of intensive agriculture for oil palm covering $60 \%$ and coffee plantation about $17 \%$. Actually, only about $61.1 \%$ of the Air Bengkulu Watershed is categorized as moderate to good quality matrix of sustainable agroecosystems. Improper agricultural cultivation with monoculture system without implemented conservation practices drove landscape filled with degradation landscapes. With sustainable agro-ecosystem scenarios implementing physical conservation terraces and restored with multi-purposes tree species such as candlenut, kapok tree, betel nut, durian, good quality of the landscape matrix of $82 \%$ Air Bengkulu Watershed.
\end{abstract}

Keywords: Air Bengkulu Watershed, land quality, land use, sustainable agro-ecosystem feature

\section{INTRODUCTION}

Last decade, concerning land resources should be managed carefully for their sustainability was more urgent than expansion land cultivation for development. Reason for that, alleviating land qualities because of mismanagement were harm our chances for accepting prospected services from the land, and requiring huge investment in soil conservation and even rehabilitation, restoration, and reclamation (Dumanski and Pieri 2000). Sustainable development in Agenda 21 from The United Nations recommended should adjust land resources management in integrated systems (Katusiisme and Schutt 2020). Land resources management on watershed applying integral planning and activities systems involved practice with water, biotics, and other resources in a certain area for ecological, social, and economic perspectives (Wang et al. 2016). Some agricultural land uses and other functions, geo-morphological landscapes, biotic, physical infrastructures, social facilities, and human activities in watershed environmental systems interact one to other and/or together to form dynamic ecosystem stabilities. Processes of structuring and managing lands, abiotic resources of water, land, and other natural resources used in a watershed through integrated watershed management were to promote the high quantity and sustainability of goods and services and at the same time could mitigate the impact on mismanagement of the soil and watershed resources (Baker et al. 2000). Watershed management with integrated systems was developed was as the fundamental principles for watershed management to harmonize diverse social, technical, and institutional interests, in tune with conservation, social, and economic purposes (German et al. 2007).

Landscape was considered one of the important determinants for ecological systems and functional region sustainability, concerning environmental, economic, and social objectives (Gavrilidis et al. 2016). Landscape fragmentation was accepted as an adverse phenomenon majorly caused by human interaction with the natural environment (Bogaert et al. 2005). Settlement development, alteration of forested lands to agricultural use (Fahrig 2001), and transportation infrastructure expansions (Geneletti 2004) were major causes of the people interference resulting fragmented landscapes. Recently, there has been an increase in consciousness about the importance of landscape fragmentation analysis (Hysa and Baskaya 2017). Watershed systems were landscapes consisted of a harmonized integrated local ecosystems providing numerous ecosystem services however in the last decade too much watershed landscapes were being endangered their functions by improper land uses, officially interfered by anthropogenic purposes. Landscape fragmentation had been tampered with chronic enlargement and invasion of agriculture, illegal logging, altering the last relics of tropical forests into remote patches (Ramirez et al. 2019). 
People-environment relations caused land-use changes triggering alleviating watersheds services for humans living downstream (Abdulkadir et al. 2019). When watershed runs into deprivation, all elements to shape and reliant on the watershed, in short, were endured. Land use converted and disproportionate human tensions on the fragile lands caused by soil productivity degradation and human carrying capacity (Yirgu et al. 2020). Furthermore, because of population growth requiring additional agricultural lands pushed traditional small-scale farmers encroached to fragile hilly terrain which ecologically sensitive (Prawitasari et al. 2017). Watershed Management as one of the serious concerns for regional planning and development in Indonesia was meeting multifaceted problems and interdependent matters. It was directed by the poor of coordination among sectors, agencies, regions, and community actions (Pambudi 2019).

Many of Indonesia's watersheds were at the level of a degraded phase. The total critical of the watersheds in Indonesia had raised from 22 in 1984 to 58 in 2000 and in 2014 the deteriorated watershed had touched 108 (Asdak and Munawir, 2017) one of them is Air Bengkulu Watershed (Mase. 2020). The degraded stage because of soil erosion and sedimentation at high rates. Various researchers had attentive to the measurements and effects of practical land uses because of land grabbing and encroachment. The improved land uses had a foremost pressure on the natural ecosystems and subsequently on the watershed environmental services (Lim and Sasaki 2016). Also, some last studies focused on conserving ecosystem's platform in design conservation practices obliged pattern explanations of the geo-diversity-the description of topographic, soil, and other abiotic settings - in a landscape (Lawler et al. 2015; Zarnetske et al. 2019). Conversions of land use and land cover in watershed were correspondingly the direct determination of landscape pattern processes (Shi et al. 2017).

The change of matrix characteristics from landscape elements in areas could convert the watershed environmental behaviors, therefore, affecting the capture ability of the landscape to reduce degradation processes of watershed productivities (Bakker et al. 2008; Guerra et al. 2015). Landscape assessment based on depiction of land characteristics and quality provided description on its potential and susceptible to watershed deprivation (Basuki et al. 2016). Furthermore, spatial distribution of land properties featuring watershed landscape was essential for various usages, for example for design watershed management. Technique to evaluate land susceptibility to deterioration for a watershed landscape or matrices was based on a watershed typology by existing land cover (Paimin et al. 2012). A landscape featuring the spatial matrices and distribution of land cover could be assessed using ordered satellite imagery (Miller et al. 2002).

Proper land-use planning based on spatial land characteristics figured watershed landscape built preconditions requisite to construct future land use which environmental sustainability principles (Ramlan et al. 2019). Furthermore, land use planning was a concept of procedure for action plan for the land-use sustainability in view of its potential characteristics, determinants and user demands. This paper presented integrated land use planning and technical conservation practices based on some soil qualities figured on spatial distribution on landscape of Air Bengkulu Watershed. Future, sustainable land use plan should be involved in understanding the Air Bengkulu Watershed therefore empowerment capacity of environmental resources on the watershed could be obtained in peak of optimum productivities and in longterm environmental services.

\section{MATERIALS AND METHODS}

The research was conducted in Air Bengkulu Watershed, Bengkulu Province, Indonesia from August to December 2019. The watershed is located in Central Bengkulu District and Bengkulu City covering 50,049.ha. Geographically, the watershed lies down between $102^{0} 14$ '48,962" E and $102^{0} 35^{\prime} 5,992^{\prime \prime} \mathrm{E}$, and between $3^{0} 37^{\prime} 8,705^{\prime \prime}$ and $3^{0} 50$ '30,802" S (Sulistyo et al. 2020). Air Bengkulu Watershed comprises 3 (three) sub-watershesd namely Susup, Rindu Hati, and Bengkulu Hilir subwatersheds (Andriansyah and Mustikasari 2011).

Secondary data required in form of watershed map of Bengkulu Province with 1: 50,000 scale, soil classification map with 1: 250,000 scale, topographic map with 1: 50,000 scale, map of Bengkulu Forest Status with scale 1: 50,000, and Landsat 8 OLI satellite imagery covering Air Bengkulu Watershed. Equipment needed for field survey involved compass, soil sample rings for not disturbed soils, and Global Positioning System (GPS). Software for data analysis used ILWIS Program version 3.4 and its hardware to process raster-based data, ArcView Version 3.3 and/or ArcGIS version 10.1, and their devices for vector-based data.

Landscape assessment depicted with spatial distribution of land properties involved $\mathrm{K}$ values of soil erodibility index, class of slope length and degree (LS), and C values of land use while $P$ values of land use plan and conservation practices based on previous researches and recommended land use. Soil samples both disturbed and not disturbed soil samples for determining $\mathrm{K}$ values based on prepared land unit map. The $\mathrm{K}$ value is determined by the soil texture, soil structure, hydraulic conductivity, and soil organic matter following formula (Wischmeier and Smith, 1978):

$$
\begin{aligned}
& 100 \mathrm{~K}=\left\{2.17 \times 10^{-4} \times(12-\mathrm{OM}) \times \mathrm{M}^{1.14}+4.20 \times(\mathrm{s}-2)+\right. \\
& 3.23 \times(\mathrm{p}-3)\}
\end{aligned}
$$

Where, K: soil erodibility index, OM: the percentage of organic matter, $\mathrm{s}$ : the class of soil structure, $\mathrm{p}$ : the class of soil permeability and $\mathrm{M}$ : $\{(\%$ clay $+\%$ very fine sand $) \mathrm{x}$ (100-\% clay)\}. K distribution pattern followed land unit map formed by overlying soil type map and slope class map. Standard erodibility indices as followed (Okorafor et al. 2018). 
Table 1. Soil erodibility indices

\begin{tabular}{lll}
\hline K value & Nature of soil & Status \\
\hline $0.0-0.1$ & $\begin{array}{l}\text { Permeable outwash drained soil, } \\
\text { slowly permeable substrata }\end{array}$ & Poor \\
$0.11-0.17$ & $\begin{array}{l}\text { Well grained soil in sandy gravel } \\
\text { free material }\end{array}$ & Slightly poor \\
$0.18-0.28$ & $\begin{array}{l}\text { Graded loams and silt loams } \\
\text { Poorly graded moderately fine- }\end{array}$ & Moderate \\
& Fairly good \\
$>0.48$ & $\begin{array}{l}\text { Poorlured soil } \\
\text { soil, well and moderately graded }\end{array}$ & Good \\
\hline
\end{tabular}

Used topographic map, index of slope length, and degree $<22 \%$ based on next equation:

$$
\mathrm{LS}=\sqrt{ }\left\{(\mathrm{La}) \times\left(1.38+0.965 \mathrm{~s}+0.138 \mathrm{~s}^{2}\right) / 100\right\}
$$

And for slopes > 22\% (Goldman et al. 1986) wrote a formula:

$$
\begin{gathered}
\mathrm{LS}=\left[\left(65.41 \times \mathrm{x} \mathrm{s}^{2}\right) /\left(\mathrm{s}^{2}+10.000\right)+(4.56 \times \mathrm{x} \mathrm{s}) /\left(\mathrm{s}^{2}+\right.\right. \\
\left.10.000)^{0,5}+0.065\right]\left[(\mathrm{La} / 22.13)^{\mathrm{m}}\right]
\end{gathered}
$$

Where, La: the slope length $(\mathrm{m}), \mathrm{s}$ : the angle of the 1 slope $(\%), \mathrm{m}$ : the constant number, the magnitude depends on the slope, i.e. $\mathrm{m}: 0.1$ if $\mathrm{S} \leq 1 \%$; $\mathrm{m}: 0.3$ if $\mathrm{S}>1 \%$ and $\mathrm{S} \leq$ $3 \%$; $\mathrm{m}$ : 0.4 if $\mathrm{S}>3 \%$ and $\mathrm{S}<5 \%$; and $\mathrm{m}: 0.5$ if $\mathrm{S} \geq 5 \%$. Used classification of soil erodibility index and slope length and degree values figured out land quality assessment (modified from Kumar and Jhariya 2015).

$C$ values were taken from the Regulation of the Minister of Forestry, Republic of Indonesia Number: P. 32/Menhut-II/2009 to draw land use indices and classification. Furthermore, land use index overlying with spatial distribution of land quality depicted landscape pattern map. Landscape pattern was derived from both abiotic such as soil type, topography, soil properties (land quality), and biotic characteristics such as absence of environmental heterogeneity figured land cover or land use (modified from Bolliger et al. 2007). Sustainable land-use plan and conservation practices were designed only in degraded landscape followed recommended and previous studies.

\section{RESULTS AND DISCUSSION}

\section{Land quality}

Erodibility index $(\mathrm{K})$ indicated soil aggregate resistance to disperse and particle transported by rainfall. Spatial distribution of $\mathrm{K}$ is revealed in Figure 1. Soil aggregates formed topsoils in Air Bengkulu Watershed dominated fairly good resistance with $\mathrm{K}$ status which cover about 25,981 ha or $51.9 \%$, high resistance about 586 ha or $1.17 \%$, and moderately resistance $\mathrm{K}$ status of soil aggregates cover about 23,485 ha or $46.9 \%$. While, there were no areas prone to aggregate disperse. In fact, inherit soil properties dominated by inceptisols and ultisols soil types cover Air Bengkulu Watershed were moderate to high resistance to disperse by rainfall attachment and the high resistance, fortunately, lies on the upstream of the Air Bengkulu area. Therefore, maintaining $\mathrm{K}$ values as soil quality attribute was important to prevent Air Bengkulu Watershed from physical degradation. Preventing soil from degradation implied a maintain in soil quality with an attendant promote in ecosystem functions and services (Lal 2015). Furthermore, maintaining soil physical properties generally prevented a reduction in structural attributes including soil organic matter, pore geometry, and continuity, thus keeping soils from crusting, structure compaction, reduced water infiltration, and increased surface runoff. Otherwise, soil degradation would be faced when the watershed landscape managed improperly. The most widespread of land degradation was caused by soil quality in a low organic and an-organic colloid fraction, high bulk density, low total porosity, and the worst determinant of low soil permeability (Widiatiningsih et al. 2018). Air Bengkulu Watershed with the upstream of the watersheds occupies on Bukit Barisan hilly terrains drain the water Indian Ocean. Short-range between the peak of the upstream and end seashore formed sharp landscape and short drainage patterns on the watersheds, resulting in overflow rainfall fast liberated to end channel in Indian Ocean (Barchia 2016).

Slope class in Air Bengkulu Watershed was shown Figure 2. Areas with slope $0-8 \%$ covered about 26,926 ha or about $53 \%$ of the watershed landscape and with wavy slope $8-15 \%$ was wide of 10,665 ha or about $21 \%$. The undulating landforms with slope $15-25 \%$ cover about 7.957 ha or $16 \%$ and hilly range in the upstream with slope 25 $45 \%$ with areas of 4,359 ha or around $8 \%$ of the whole watershed and the rest with slope more than $45 \%$ only occupy 1,401 ha. Soils with slope more than $8 \%$ without dense land cover or improper land use management could decrease their productivities because of raindrop detachment and particle transported by runoff. Land quality was the combined characteristics, state, or "health" of the land comparative to human desires, involving agricultural cultivations, forestry, conservation, and environmental services (Dumanski et al. 1998). Maintaining land quality was an important factor to prevent the damage of land resources in watershed (Suryani and Tarigan 2009). Land quality could be determined by combining some land characteristics in land unit (Jayanti et al. 2013). Lack of proper land management and land use were factors that most influence the degradation of land in watershed (Andriyanto et al. 2015). Other factors, furthermore, of land degradation significantly promoted by soil erosions, were marginal soil characteristics such as low content of soil organic matter and low hydraulic conductivity, and slope length and degree. 


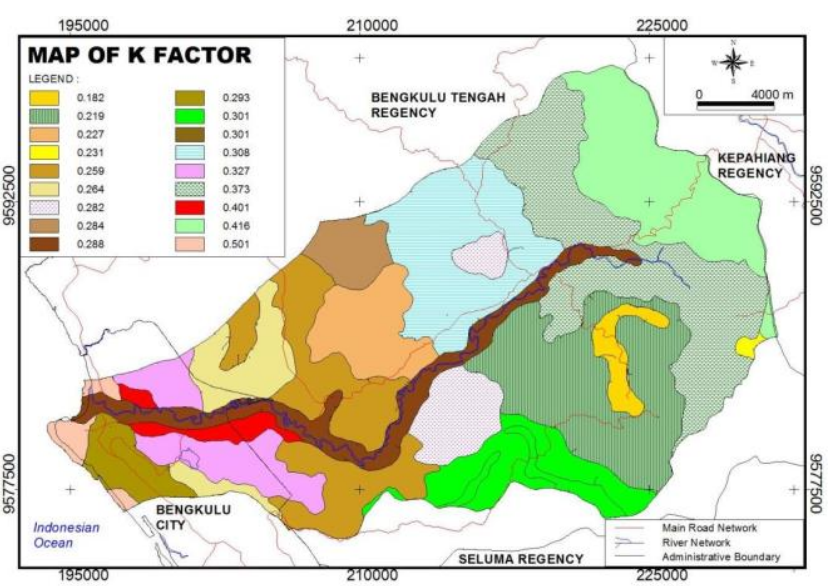

Figure 1. Erodibility index in Air Bengkulu Watershed, Bengkulu Province, Indonesia

Land quality assessment in Air Bengkulu Watershed based on combination of land quality of $\mathrm{K}$ values and of slope length and degree dominated moderately quality class with covering areas 16,579 ha or $33.1 \%$ from the watershed landscape and distributed from upstream to downstream of the watershed landscape. Land quality in marginal conditions occupies 13.459 ha or $26.9 \%$ lies on coastal areas to Bukit Barisan hilly range especially widespread on undulating and foothills areas. Areas suitable for agriculture activities and potential good environmental services covered about 14.016 ha or $28.0 \%$ of the landscape. Distribution land quality classification was shown in Figure 3.

The worst land quality 5,997 ha or $12.0 \%$ of the area lies on the hilly range with steep slope closed to peak landscape of this area and the determinant factor influences the land quality of the Air Bengkulu landscape was slope gradient. The upstream of the Air Bengkulu Watershed covered by rolling landscape with steep slope was potentially susceptible to degrade land productivities by runoff erosion. Comparing to other researches, generally, landscape degradation in Juana watershed happened in the upper stream where the steep slope gradient was $25-40 \%$ and the land was used for dry agriculture cultivation (Pramono 2014). Land degradation as a result of soil erosion improved following the increase of the slope degree with the critical slope gradient of $15^{\circ}$ for replanting with tree crops the farmland to forest or agroforestry (Zhang et al. 2015). The struggles facing soil deterioration and lack of productivity of agricultural land use were severe in the countryside at highlands of Ethiopia which land quality degradations in the rural were mainly affected by water erosion because of rugged topography (Dagnachew et al. 2020).

\section{Agro-ecosystem landuse}

Respond to Indonesia government policies stimulated oil palm expansion which the government regulated direct

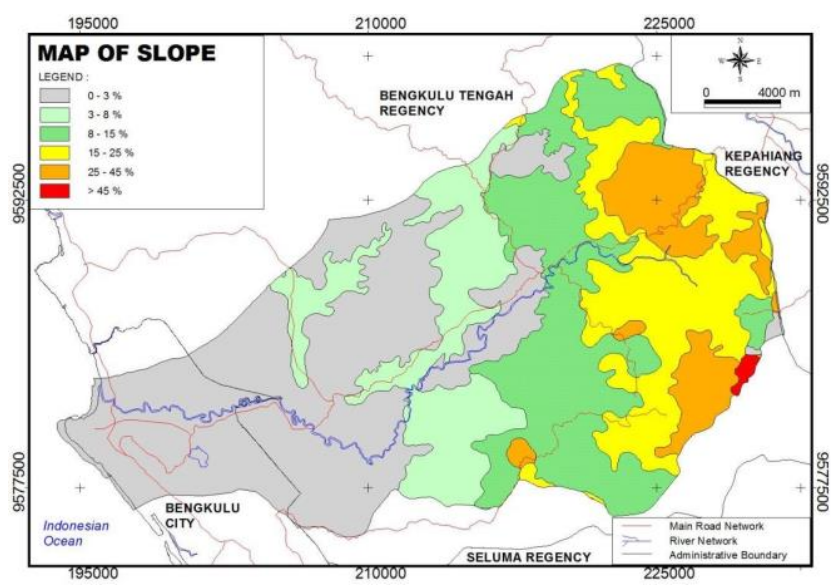

Figure 2. Slope class in Air Bengkulu Watershed, Bengkulu Province, Indonesia

systems in promoting investments in oil palm plantation through provincial governmental agencies with direct involvements in service provision, institutional facilities, agriculture extension, and admission to land and capital, oil palm plantation developed in this area by medium-scale companies as well as locals farmers. Today, oil palm plantation covers dominant land use on the landscape of Air Bengkulu Watershed. Spatial distribution of land use on Air Bengkulu Watershed was depicted in Figure 4.

Oil palm plantation is widespread over 30,391 ha or about $60 \%$ of the whole landscape of Air Bengkulu Watershed. The expansion of oil palm estate had received forced with criticism of being environment-destroying activities (Rushayati et al. 2017). Agricultural soils with oil palm cultivations were generally more deteriorated than under cultivated other agricultural lands such as rubber plantation showing lower in soil carbon and stocks, lower total soil nitrogen, and higher bulk density (Guillaume et al. 2016). Oil palm estate and traditional plantation generally promote a lowering in water storage, improving in annual water flow out from the total amount of water runoff, and a deteriorate in water quality, but these deviations inclined to become less severe as plantations mature (Comte et al. 2012) and could be restored to some prosperity with good management (Yusop et al. 2007). Furthermore, oil palm expansions in general viewpoint had decreased ecosystem services comparing to forests: 11 out of 14 ecosystem services revealed a net lowering in service level. Some attributes figured deteriorated with hypothetically permanent global effects, for instance, imbalances in gas and climate cycles, flora and fauna habitat and nursery spaces, genetic resources, medical plant resources, and information functions (Dislich, et al. 2016). Improving good quality of landscape matrices in oil palm plantation, lands with high slope gradient, and riverbanks could be replanted with tree crops and could be corridors for fauna movement. 


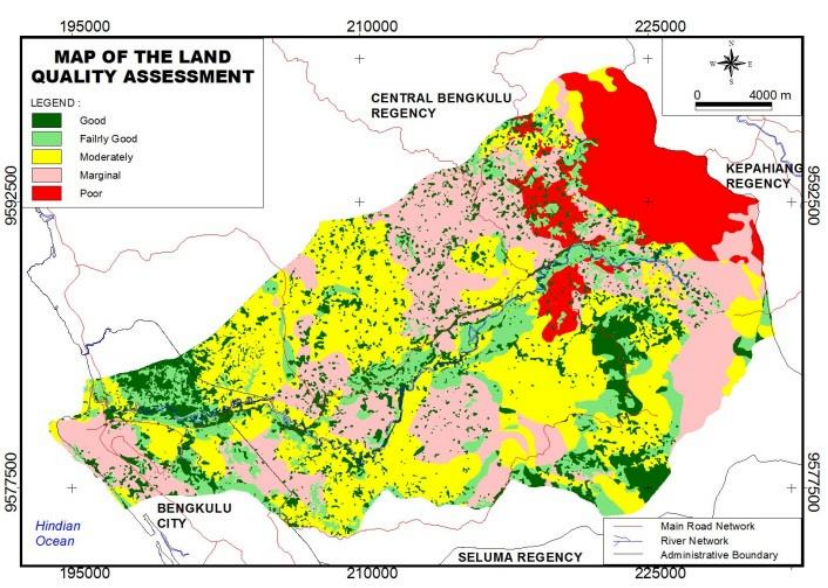

Figure 3. Land quality assessment in Air Bengkulu Watershed, Bengkulu Province, Indonesia

Also, stands 2 (two) rubber processing plants in this area however today land use for rubber plantation covers 674 ha remains. Oil palm usually converts other cash or subsistence crops, for example, rubber crop and further oil palm expansions had caused water scarcity a topic in the human concerns (Merten, et al. 2016). Rubber plantation was often converted to oil palm and also latest oil palm expansion replaced foods cropland rather than natural ecosystems (Saswattecha, et al. 2015).

Agroforestry with coffee plantation mixed with forest cover about 8.805 ha or about $17 \%$ of the Air Bengkulu Watershed and these occupy on hilly range areas especially covers on Bukit Daun protected forest. Actually, agroforestry-coffee stands on steep slope of hilly range formed structure landscape as forest patches and corridors and matrix providing ecological connectivity for the migration of organisms, for gene flow, and for range shifts, and thus was an important determinant in the long-term sustainability of populations, especially for animal species (Liu, et al. 2018). Protected forests involved natural reserve forest in Air Bengkulu Watershed covers 13,053 ha or 23\% of the area including Danau Dendam natural forest tourism area with wide of 577 ha. In Bukit Daun protected forest lies on the Bukit Barisan hilly range is habitat for endangered species Rafflesia arnoldi. The habitat of the biggest flower in the world, Rafflesia arnoldi should be protected from distracted visitors, and local tourist guides should have knowledge about the importance of the big flower for tourism attraction in Bengkulu. Also, in the Danau Dendam conservation natural ecosystems is habitat for endangered orchid species Crinum asiaticum. This area lies in Bengkulu City and closed to infrastructure development for social facilities therefore the infrastructure construction should consider preservation of the orchid Crinum asiaticum habitat.

Wide areas of paddy's fields on the Air Bengkulu Watershed are 3,569 ha or 7\% lies on river embankment plane from the upstream until closed to coastal plain. Most of the rice fields are water supply from Air Bengkulu River with fluctuation water debit so high between rainy season and dry season. Flood and drought occurrences causing

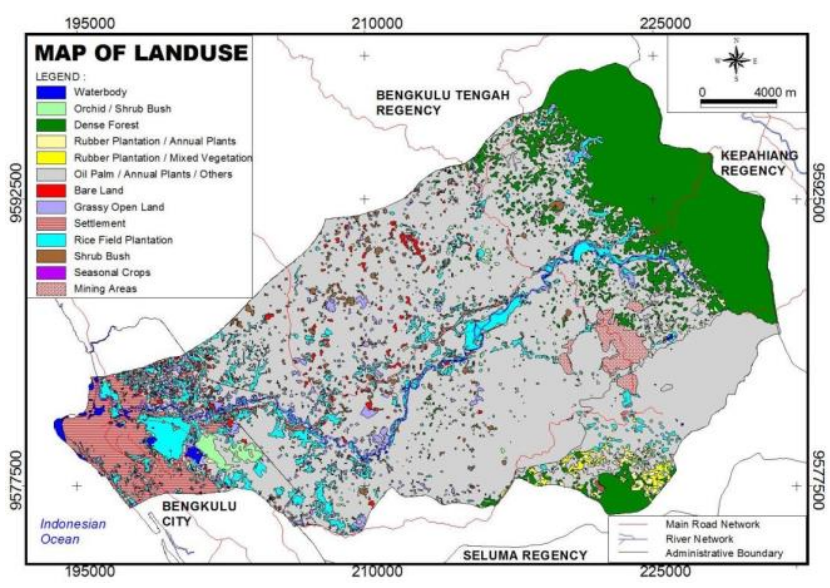

Figure 4. Land use in Air Bengkulu Watershed, Bengkulu Province, Indonesia

harvested failures are often faced with rice farmers in this area. Harvest failures of rice cultivation because of flood, water supply limited, and pests and disease attacks could be driven factors for rice farmers in this area to convert paddy fields to oil palm plantation. Rubber, coffee, and paddy are traditional crops cultivated by local farmers which are inherited from previous generations.

The worst land cover found in the Air Bengkulu Watershed is coal mining areas. Mining activities caused depletion of the watershed involving soil, land, water, habitat, biodiversity, and other ecosystem services. Openpit mining method caused destroyed natural landscape, soil structure, changes soil characteristics, and leaving on ecoenvironmental destructions such as limited vegetation growth, soil erosion, damage in topographic conditions and hydrologic cycles, and deteriorated agricultural land and topsoil (Guo, et al. 2018). In mining regions, the lands were damaged by various coal mining actions i.e. blasting, drilling, placing of overburden materials, land cutting, construction of additional facilities, and vehicles moving. Various wastes such as trace elements, inorganic substances, toxic materials, and organic materials were discharged from various activities of coal mining operations (Rai and Paul 2011).

Social infrastructures and facilities growth fast on landscape of Air Bengkulu Watershed because Bengkulu City as capital city of Bengkulu Province and Central Bengkulu District as newly developed district needed expanding housing and social facilities. These facilities are developed in suitable areas with limited physical constraints for human activities thus expansion of settlements threat existing agricultural lands closed to the cities. Bare lands found on watershed about 2,000 ha are mostly prepared lands for housing, government building, and social facilities by private sectors and government.

\section{Agro-ecosystem landscape feature}

Human habitat damage and shattered generally affected ecosystem services provided by dense and secondary forests, bushes, and grasslands within landscapes on spatial and temporal gradations (Tolessa, et al. 2016). Soil organic 
content and water holding capacity were the important soil characteristics prone to degrade because of land-use change from densely covered tree crops to intensive agricultural cultivation (Hermawan, et al. 2020). Ecosystem damages and disintegration were non-accidental manners in which the land-use changes of forestland or previous land functions for agricultural cultivation to other cropland cultivation, housing, and other land use. The damages were commenced deliberately by farmers considered upon potential productivity of the land for agro-ecosystem production and economic yield, closed to accessibility and settlement centers, topography, and water availability and drainage facilities. In this case, the agro-ecosystem landscape assessment would be described in 5 (five) classes through combining analysis from land quality and land use on the Air Bengkulu Watershed. Agro-ecosystem landscape assessment on the watershed facilitated comparisons between different geographic areas within the same area which the fragmentation depended on the different land use or land cover. The landscape matrix of the fragmented agro-ecosystem on Air Bengkulu Watershed is depicted in Figure 5.

Landscape on agroforestry coffee mixed with secondary forest on the upstream with the most fragile land quality class generally lying on protected forest areas however are still good condition assumed with variegated to intact habitats. Also in downstream with coastal areas and flat contour covering with paddy fields and Danau Dendam natural forest area, the landscapes are fairly good to good condition assumed with variegated habitats. The fairly good and good assumed with variegated habitats for landscape services cover respectively 3,970 ha or $8 \%$ and 18,023 ha or $36 \%$ of the Air Bengkulu Watershed while moderately class from the agro-ecosystem landscape service cover 4,898 ha or about $10 \%$ of the area. Vegetative buffers with agroforestry systems were significant features that stand in various configurations in human landscapes (Lee et al. 2003). Furthermore, the agro-ecosystem landscape with agroforestry model could provide different functions to serve or control water flows, other natural resources, or specific organisms. Widespread root systems of tree plants in tree zones resisted soil in stabile conditions, maintained great infiltration rate of water, and grasp the sediment entering to close down sites. The agroecosystem with agroforestry could reduce the severity of flooding downstream of watershed landscape by breaking surface runoff and raising the water infiltration rate into soils (Schultz et al. 1997). Many researchers proposed that perennial trees zones also promoted indirect ecological services, such as improving the biodiversity richness of biotic flora and fauna, and ensuring habitat for wildlife. Agro-forestry models could maintain the microclimate with their shadow plants (Bolund and Hunhammar 1999), in this area shadow plants for coffee crops could maintain microclimate in the root zone. The shadow plants for coffee could use kapok (Ceiba pentandra), petai (Parkia speciosa). Agro-ecosystem landscapes with moderate assessment are covered by multi-local species crops lying on undulating areas closed to poor class of the matrix landscape.

The matrix of the agro-ecosystem landscapes with marginal and poor classes occupied 11,039 ha or $22 \%$ and 12,120 ha or $24 \%$ respectively distributed on the middle areas of the Air Bengkulu Watershed. The land use on this class widespread generally covered by oil palm plantation stands on undulating physiographical contour. Landscape matrix dominantly covered by monoculture agricultural systems were likely low species richness. Expansion of mono-crop system in agriculture was the significant factor causing a biodiversity impoverished, deterioration in structural density and heterogeneity of vegetation, and consequent lowering in shade systems, revamping microclimate, and damaging soil physical and chemical properties (Luke, et al. 2020). The availability of suitable agricultural areas limited had promoted to spreading out of oil palm plantation into fragile lands such as land with great steepness (Afandi, et al. 2017). Land degradation by erosion then became an alarm, with the depletion of soil fertilities and lack of water holding capacity, consequently affecting in plant nutrient deficiency, drainage freshwater and groundwater polluted along with other ecological surrounding alterations. Furthermore, land degradation because of erosion on oil palm cultivation was high related to rugged landscape, which soil erosion rate followed to greater land steepness. Downstream from the upper erosion lands, the enlarged delivery of fine sediments could lessen capacity of river as a channel directing to amplify flood occurrences, and had adverse effects on water upon quality through increased turbidity and nutrient concentrations (Tan-soo et al. 2014). Deterioration in compact natural vegetation habitats had caused harmonized drops of the physical and biotic interaction within environments, which was a depth concern for the watershed ecosystem services (Martin, et al. 2018).

\section{Sustainable agroecosystems land use plan}

Small-scale farming stood on great steepness slope land was related to severe soil erosion, deterioration of soil health, and damaging agricultural land sustainability (Barrowclough, et al. 2016). Furthermore, sustainable agriculture offers limited destruction of land and upkeep of continuous groundcover, two conservation agriculture principles, alleviated soil erosion, and could improve soil health and productivity. The rehabilitation and conservation of the land quality values were important strategies leading to attainment of sustainable agroecosystem management (Luangduangsitthideth, et al. 2018). Agroecosystems plan for sustainable agriculture landscape in Air Bengkulu Watershed was revealed in Figure 6. 


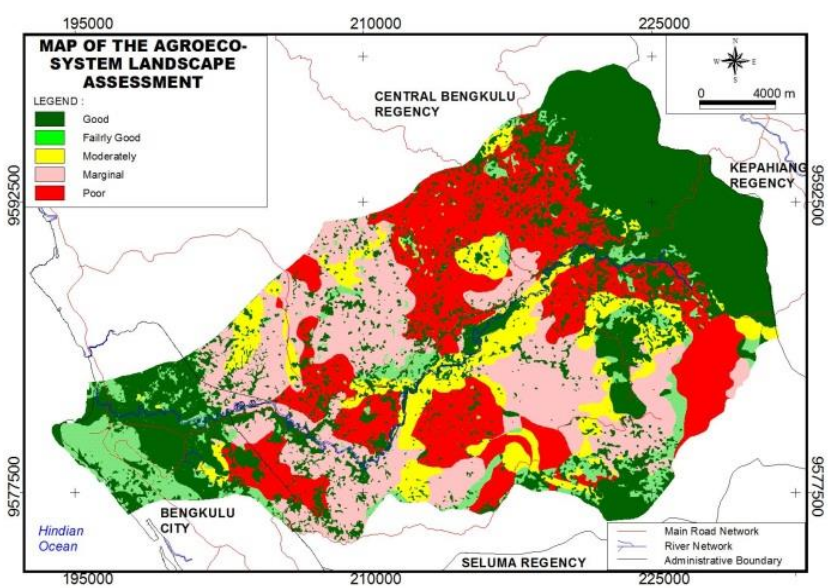

Figure 5. Agro-ecosystem landscape assessment in Air Bengkulu Watershed, Bengkulu Province, Indonesia

Current sustainable agroforestry landscapes on the upstream of the watershed, multi-local crop agroecosystem in the middle of watershed landscape, and paddy fields in riverside alluvial plains and flat landscape in the downstream should be maintained. Agroforestry was conceivably as old as agricultural development itself with apply of planting perennial crops and cash crops on the one unit of land assimilated with current technological agroforestry practices used multi-purposes tree species and economic prospects for small scale farmers could be appropriate approach to addressing environmental issues. Some local species gave additional income for local farmers implemented agroforestry such as candlenut, jackfruit, breadfruit, durian, petai, and betel nut. With sustainable agro-ecosystem scenario implementing erosion preventing ridge on the waving landscape and constructing bench terrace on the undulating the agro-ecosystems areas on the Air Bengkulu Watershed, the landscape matrix with moderately to good performances extend significantly. Watershed ecosystems recovered to moderate and highclass qualities through enrichment planting following suitability and the legal function of the area, implementing soil and water conservation practices with vegetative and civil engineering techniques (Kadir, et al. 2016). The enrichment vegetation applied could be used tree plants such as candlenut, kapok, betel nut, durian, breadfruit, and jackfruit.

The moderately, fairly good, and good performances on the landscape mosaic are respectively 11,453 ha, 11,036 ha, and 18,747 ha, or $82 \%$ of Air Bengkulu Watershed area. Areas with marginal and poor matrix quality of the watershed landscape are 5,205 ha and 3,608 ha or both about $18 \%$ of the watershed landscape. Scenarios implemented conservation practices on the fragile agroecosystems eliminate current marginal and poor matrix quality on the watershed landscape from 23,159 ha to 8,813 ha or 14,346 ha could be restored for sustainable agroecosystems on Air Bengkulu Watershed. Some areas of agricultural lands with steep slope covering coffee without shade trees and ground cover cleaned are cultivated

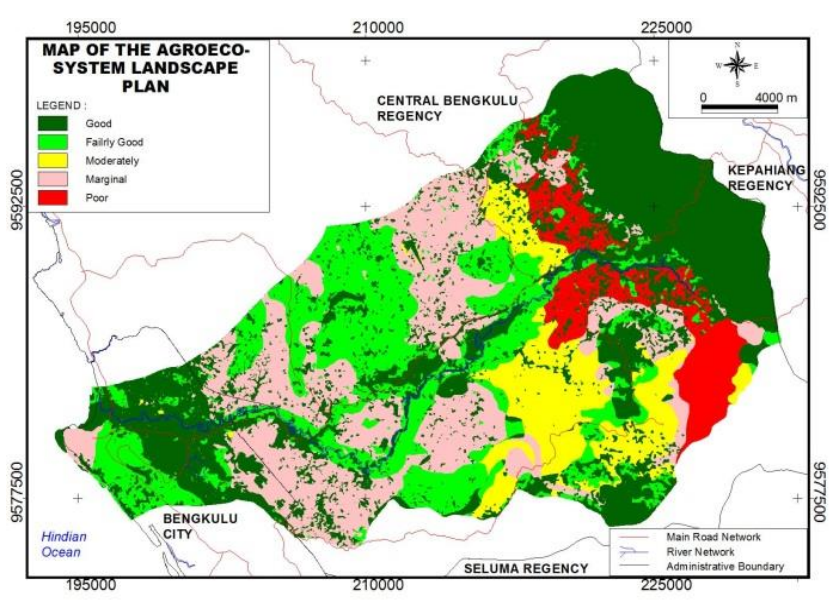

Figure 6. Agro-ecosystem landscape plan in Air Bengkulu Watershed, Bengkulu Province, Indonesia

by traditional farmers assumed difficult to introduce sustainable agroecosystem practices. Also, oil palm areas on foothill areas and rough physiographical matrices cultivated by small scale farmers still in poor conditions because of lack of conservation knowledge and capital for implemented physical conservation practices. Empowerment of the small scale farmers both cultivated coffee and oil palm should be done to improve their knowledge and practices. Knowledge and skill of sustainable agriculture such as implementing organic fertilizers, choice of multi crops, small mounds for sediment traps, and water harvesting with small pond. With implemented these, in short, about $18 \%$ of the areas with still degraded lands or $82 \%$ areas of the Air Bengkulu Watershed covered with moderate to good landscape matrix after implemented sustainable agro-ecosystem scenarios, future performance of the landscape structure in Air Bengkulu Watershed could foster agricultural landscape environmental friendly.

In conclusion, inherit soil quality based on soil physical properties in Air Bengkulu Watershed actually classified moderate to good suitable for sustainable agroecosystem activities however the watershed lays on in short-range between upstream to downstream landscape. This unique landscape formed a fragile land quality for intensive agricultural activities therefore agriculture land cultivations should be in wise land uses. In fact, only $28.0 \%$ of the watershed is covered by fairly good to good landscape matrix of sustainable agro-ecosystem while $38.9 \%$ is undergoing degradation processes and classified with unhealthy agro-ecosystems. Implementing wise land uses especially in steep slope and riverbanks with multi crops using candlenut, jackfruit, breadfruit, and durian could increase the quality of matrices landscapes. With scenarios of sustainable agro-ecosystem plan implementing organic fertilizers, choice of multi crops, small mounds for sediment traps and water harvesting with small pond, mosaic of the Air Bengkulu landscape could figure wise agro-ecosystem matrix $82 \%$ of Air Bengkulu Watershed with sustainable agro-ecosystems features. 


\section{REFERENCES}

Abdulkadir TS, Muhammad RUM, Yusof KW, Ahmad MH, Aremu SA Gohari A, Abdurrashed AS, Lervolino M. 2019. Quantitative analysis of soil erosion causative factors for susceptibility assessment in a complex watershed. Cogent Eng 6 (1): 1594506. DOI: 10.1080/23311916.2019.1594506.

Afandi AM, Zuraidah Y, Nurzuhaili HAZA, Zulkifli H, Yaqin M. 2017 Managing soil deterioration and erosion under oil palm. Oil Palm Bull 75: $1-10$.

Andriansyah O, Mustikasari R. 2011. Gambaran umum permasalahan pengelolaan air Das Air Bengkulu. Telapak dan Both ENDS, Belanda. [Indonesian]

Andriyanto C, Sudarto, Suprayogo D. 2015. Estimation of soil erosion for a sustainable land use planning: RUSLE model validation by remote sensing data utilization in the Kalikonto watershed. J Degrad Mining Lands Manag. DOI: 10.15243/jdmlm.2015.031.459.

Asdak C, Munawir. 2017. Integrated water resources conservation management for sustainable food security. Knowledge E. DOI 10.18502/kls.v2i6.1045.

Baker MB, Folliott PF, Edminster CB, Mora KL, Dillon MC. 2000 Watershed management contributions to land stewardship: A literature review. General Technical Report RMRS-GTR-71WWW. U.S. Department of Agriculture, Forest Service, Rocky Mountain Research Station, Fort Collins, CO.

Bakker MM, Govers G, van Doorn A, Quetier F, Chouvardas D Rounsevell M. 2008. The response of soil erosion and sediment export to land-use change in four areas of Europe: The importance of landscape pattern Geomorphology. DOI: 10.1016/j.geomorph.2006.12.027.

Barchia MF. 2016. Option for land conservation practice based on land uses in Kungkai watershed, Bengkulu, Sumatera, Indonesia. Intl Environ Sci Dev 7 (3): 221-224.

Barrowclough M, Stehouwer R, Alwang J, Gallagher R, Mosquera VHB, Dominguez JM. 2016. Conservation agriculture on steep slope in the Andes: Promise and obstacles. J Soil Water Conserv 71 (2): 91 -102.

Basuki TM, Wijaya WW, Wahyuningrum N. 2016. Spatial distribution of land susceptibility to degradation and recommendation for its improvement: a case study in the upper Solo Sub-Watershed. J Degrad Mining Land Manag. DOI: 10.15243/jdmlm.2016.041.689.

Bogaert J, Farina A, Ceulemans R. 2005. Entropy increase of fragmented habitats: A sign of human impact? Ecol Indicat. DOI 10.1016/j.ecolind.2005.02.002.

Bolliger J, Wagner HH, Turner MG. 2007. Identifying and quantifying landscape patterns in space and time. In: Kienast F, Wildi O, Ghosh S. (eds.) A Changing World. Landscape Series, vol 8. Springer, Dordrecht. DOI: 10.1007/978-1-4020-4436-6_12.

Bolund P, Hunhammar S. 1999. Ecosystem services in urban areas. Eco Econ. DOI: 10.1016/S0921-8009(99)00013-0

Budidarsono S, Susanti A, Zoomers A. 2013. Oil palm plantation in Indonesia: The implication for migration, settlement/resettlement and local economic development. Biofuels-Economy, Environment and Sustainability. Intech, Rijeka. DOI: 10.5772/53586

Comte I, Colin F, Whalen JK, Grunberger O, Caliman JP. 2013 Agricultural practices in oil palm plantations and their impact on hydrological changes, nutrient fluxes and water quality in Indonesia: A review. Adv Agron 116: 71-124.

Dagnachew M, Moges A, Kebede A, Abebe A. 2020. Measures on Soil Quality Indicators: The Case of Geshy Subcatchment, Gojeb River Catchment, Ethiopia. Appl Environ Soil Sci 2020: 1868792. DOI: $10.1155 / 2020 / 1868792$

Dislich C, et al. 2016. A review of the ecosystem functions in oil palm plantations, using forests as a reference system. Biol Rev. DOI $10.1111 /$ brv. 12295

Dumanski J, Gameda S, Pieri C. 1998. Indicators of land quality and sustainable land management, An Annotated Bibliography. The World Bank. Washington DC.

Dumanski J, Pieri C. 2000. Land quality indicators: research plan. Agric Ecosyst Environ 81: 93-102.

Fahrig L. 2001. How much habitat is enough? Biol Conserv. DOI 10.1016/S0006-3207(00)00208-1

Gavrilidis AA, Ciocanea CM, Nita MR, Onose DA, Nastase II. 2016. Urban Landscape Quality Index-planning tool for evaluating urban landscapes and improving the quality of life. Procedia Environ Sci. DOI: 10.1016/j.proenv.2016.03.020.
Geneletti D. 2004. A GIS-based decision support system to identify nature conservation priorities in an alpine valley. Land Use Pol. DOI: 10.1016/j.landusepol.2003.09.005

German L, Hussein M, Getachew A, Waga M, Amede T, Stroud A. 2007. Participatory integrated watershed management: Evolution of concepts and methods in an eco-regional program of the eastern African highlands. Agric Syst 94 (2): 189-204.

Goldman SJ, Jackson K., Bursztynsky TA. 1986. Erosion and Sediment Control Handbook. McGraw-Hill, New York.

Guerra CA, Metzger MJ, Maes J, Pinto-Correia T. 2015. Policy impacts on regulating ecosystem services: looking at the implications of 60 years of landscape change on soil erosion prevention in a Mediterranean silvopastoral system. Landsc Ecol 31: 271-290.

Guillaume T, Holtkamp AM, Damris M, Brummer B, Kuzykov Y. 2016. Soil degradation in oil palm and rubber plantations under land resource scarcity. Agric Ecosyst Environ. DOI: 10.1016/j.agee.2016.07.002.

Guo X, Zhao T, Chang W, Xiao C, He Y. 2018. Evaluating the effect of coal mining subsidence on the agricultural soil quality using principal component analysis. Chilean J Agric Res 78 (2): 173-182.

Hermawan B, Suhartoyo H, Sulistyo B, Murcitro BG, Herman W. 2020. Diversity of soil organic carbon and water characteristics under different vegetation types in Northern Bengkulu, Indonesia. Biodiversitas 21: 1793-1799. DOI: 10.13057/biodiv/d210504

Hysa A, Baskaya FAT. 2017. Landscape fragmentation assessment utilizing the Matrix Green Toolbox and CORINE Land Cover Data. J Digital Landsc Architect 2: 55-62.

Jayanti DS, Goenadi S, Hadi P. 2013. Land suitability evaluation and land use optimization for cacao (Theobroma cacao L.) development (case study in Batee District and Padang Tiji District, Pidie Sub-Province, Aceh Province). Agritech 33 (2): 208-219.

Kadir, S, Badaruddin, Nurlina, Ridwan I, Rianawati, F. 2016. The recovery of Tabua watershed through enrichment planting using ecological and economically valuable species in South Kalimantan, Indonesia. Biodiversitas 17 (1): 140-147. DOI: 10.13057/biodiv/d170121.

Katusiisme J, Schutt B. 2020. Linking land tenure and integrated watershed management-A review. Sustainability 12 (4): 1667. DOI: $10.3390 / \mathrm{su} 12041667$

Kumar T, Jhariya DC. 2015. Land quality index assessment for agricultural purpose using multi-criteria decision analysis (MCDA). Geocarto Intl 30 (7): 822-841. DOI: 10.1080/10106049.2014.997304.

Lal R. 2015. Restoring soil quality to mitigate soil degradation. Sustainability 7 (5): 5875-5895. DOI: 10.3390/su7055875.

Lawler JJ, Ackerly DD, Albano CM, Anderson MG, Dobrowski SZ, Gill JL, Heller NE, Pressey RL, Sanderson EW, Weiss SB. 2015. The theory behind, and the challenges of, conserving nature's stage in a time of rapid change. Conserv Biol 29: 618-629. DOI: 10.1111/cobi.12505.

Lee KH, Isenhart TM, Schultz RC. 2003. Sediment and nutrient removal in an established multi-species riparian buffer. J Soil Water Conserv 58 (1): $1-8$

Lim L, Sasaki Y. 2016. Review of research trends in watershed-based land use analysis. J ISCE 4: 227-242. DOI: 10.2208/journalofjsce.4.1_227.

Liu C, Newell G, White M, Bennett A, Yue BS. 2018. Identifying wildlife corridors for restoration of regional habitat connectivity: A multispecies approach and comparison of resistance surface. PLoS ONE 13 (11): e0206071. DOI: 10.1371\%2Fjournal.pone.0206071.

Luangduangsittihideth O, Limnirankul B, Kramol P. 2018. Farmer's knowledge and perception of sustainable soil conservation practices in Paklay distric, Saybouly province, Lao PDR. Kasetsart J Soc Sci. DOI: 10.1016/j.kjss.2018.07.006.

Luke SH. et al. 2020. Managing oil palm plantations more sustainability: Large scale experiments within the biodiversity and ecosystem function in tropical agriculture (BEFTA) programme. Front For Glob Change 2: 75. DOI: 10.3389/ffgc.2019.00075.

Martin RN, Abrahao SA, Ribeiro DP, Colares APF, Zanella MA. 2018. Spatio-temporal analysis of landscape patterns in the Catole watershed, Northern Minas Gerais. Revista Árvore 42 (4): 1-11. DOI: 10.1590/1806-90882018000400007.

Mase LZ. 2020. Slope Stability and Erosion-Sedimentation Analyses Along Sub-watershed of Muara Bangkahulu River in Bengkulu City, Indonesia. E3S Web Conf 148: 03002. DOI: $10.1051 / \mathrm{e} 3$ sconf/202014 
Merten J. et al. 2016. Water scarcity and oil palm expansion: social views and environmental processes. Ecol Soc 21 (2): 5. DOI: 10.5751/ES08214-210205.

Miller SN, Kepner WG, Mehaffey, MH, Hernandez M, Miller RC, Goodrich DC, Devonald KK,. Heggem DT, Miller, WP. 2002. Integrating landscape assessment and hydrological modeling for land cover change analysis. J Amer Water Res Assoc 38 (4): 915-929.

Okorafor OO, Akinbile CO, Adeyemo AJ. 2018. Determination of soil erodibility factor $(\mathrm{K})$ for selected sites in Imo State, Nigeria. Resour Environ 8 (1): 6-13.

Paimin, Pramono IB, Purwanto, Indrawati DR. 2012. Sistem perencanaan pengelolaan daerah aliran sungai. Pusat Penelitian dan Pengembangan Konservasi dan Rehabilitasi (P3KR). Bogor. [Indonesian]

Pambudi AS. 2019. Watershed Management in Indonesia: A regulation, institution, and policy review. Indon J Dev Plan 3 (2): 185-202. DOI 10.36574/jpp.v3i2.74

Pramono IB. 2014. Mitigation of land degradation at Juana Watershed, Central Java. J Degrad Min Land Manag 2 (1): 211-218. DOI: 10.15243/jdmlm.2014.021.235.

Prawitasari M, Lee CY, Setyawan C. 2017. Application of GIS for degradation level assessment in tropical watershed. Intl J Sci Technol Res 6 (2): 109-113.

Rai AK, Paul B. 2011. Degradation of soil quality parameter due to mining operations in Jharia Coalfield, Jharkhand, India. J Adv Lab Res Biol 2 (2): 51-56.

Ramirez MAM, Pulhin JM, Garcia JE, Tapia MA, Pulhin FB, Cruz RVO, Luna CCD, Inoue M. 2019. Landscape fragmentation, ecosystem services, and local knowledge in the Baroro River Watershed, Northern Philippines. Resources 8 (4): 164 . DOI: 10.3390/resources8040164

Ramlan, Rahman A, Faisal, Sutrisno, M. 2019. Land use and environmen physical condition on sedimentation and water discharge of Lindu lake watershed. Intl $\mathbf{J}$ Chem Mater Sci 2 (1): 1-7. DOI: 10.31295/ijcms.v2n1.71.

Rushayati SB, Hermawan R, Meilani R. 2017. Global warming mitigation through the local action of environmental education in the plantation area of palm oil. Forum Geografi 30 (2): 140-149. DOI: 10.23917/forgeo.v31i1.3861

Saswattecha K, Hein L, Kroeze C, Jawjit W. 2015. Effects of oil palm expansion through direct and indirect land-use change in Tapi river basin, Thailand. Intl J Biodiv Sci Ecosyst Serv Manag 12 (4): 1-23. DOI: 10.1080/21513732.2016.1193560.

Schultz, RC, Kuehl A, Colletti JP, Wray PH, Isenhart TM. 1997. Riparian Buffer Systems. Agriculture and Environment Extension Publications No. 219. Iowa State University, Ames, IA.
Shi P, Zhang Y, Li Z, Li P, Xu G. 2017. Influence of land use and land cover patterns on seasonal water quality at multi-spatial scales. Catena 151: 182-190. DOI: 10.1016/j.catena.2016.12.017

Sulistyo B, Barchia MF, Hindarto KS, Listyaningrum N. 2020. The effect of land unit elimination of the conservation activity plan at Air Bengkulu Watershed, Bengkulu Province. Indonesian J Geography 52 (2): 170-180. DOI: 10.22146/ijg.48578.

Suryani, Tarigan SD. 2009. Optimasi perencanaan penggunaan lahan menggunakan system informasi geografi (SIG) dan soil and water assessment tool (SWAT) (Suatu studi di DAS Cijalupang, Bandung Jawa Barat. Jurnal Ilmu Tanah dan Lingkungan 11 (2): 63-70. DOI: 10.29244/jitl.11.2.63-70.

Tan-soo J.S, Adnan N, Ahmad I, Pattanayak SK., Vincent J.R. 2014. Economic evidence on forest ecosystem services: Deforestation and flooding in Malaysia. Environ Resour Econ 63: 25-44.

Tolessa T, Senbeta F, Kidane M. 2016. Landscape composition and configuration in central highlands of Ethiopia. Ecol Evol. DOI: 10.1002/ece3.2477.

Wang G, Mang S, Cai H, Liu S, Zhang Z, Wang L, Innes J.L. 2016. Integrated watershed management: evolution, development and emerging trends. J For Res 27: 967-994.

Widiatiningsih A, Mujiyo, Suntoro. 2018. Study of soil degradation status at Jatipurno District, Keduang Sub-watershed, Wonogiri Regency, Central Java. Sains Tanah-J Soil Sci Agroclimatol 15 (1): 1-14. DOI: 10.15608/stjssa.v15i1.862.

Wischmeier WH, Smith DD. 1978. Predicting Rainfall Erosion Losses. A Guide to Conservation Planning. USDA. Agriculture Handbook No. 537. U.S. Government Printing Office, Washington, D.C.

Yirgu T, Yihunie Y, Assele A, Wogayehu T. 2020. Land capability analysis and delineation of erosion prone areas in the case of Kulfo watershed, Abaya Chamo Basin. Afr J Environ Sci Technol 14 (3): 83-91. DOI: 10.5897/AJEST2020.2829.

Yusof Z, Chan CH, Katimon A. 2007. Runoff characteristics and application of HEC-HMS for modelling stormflow hydrograph in an oil palm catchment. Water Sci Technol 56 (8): 41-48. DOI: 10.2166/wst.2007.690.

Zarnetske PL, Read QD, Record S, Gaddis K, Pau S, Hob, M, Malone S, Costanza J, Dahlin KM, Latimer AM, Wilson AM, Grady J, Ollinger, SV, and Finley, AO. 2019. Towards connecting biodiversity and geodiversity across scales with satellite remote sensing. Glob Ecol Biogeogr. DOI: 10.1111/geb.12887.

Zhang Z, Sheng L, Yang J, Chen XA, Kong L, Wagan B. 2015. Effects of land use and slope gradient on soil erosion in a red soil hilly watershed of Southern China. Sustainability 7 (10): 14309-14325. DOI: $10.3390 / \mathrm{su} 71014309$. 